\title{
The Effect of Paired Conversation Activity by Utilizing News-Based Materials in Improving the Students' Speaking Skill
}

\author{
Khadijah Maming, Raya Mangsi \\ Universitas Muhammadiyah Parepare \\ Address: Jend. Ahmad Yani KM 6 Soreang, Parepare, Indonesia \\ Email:khadijahmaming@gmail.com
}

\begin{abstract}
The objective of this study focused on the effect of paired conversation activity by utilizing newsbased materials in improving the students' speaking skill. The students were supposed to comprehend the content of news-based materials and then explain and conclude the essential things from the news orally. It was focused on improving the students' productive skill that is speaking skill. This research covered different topics of news taken from some resources such as; international yahoo news, BBC news, YouTube, magazine, and other mass media. In this research, the students also be expected to search and discover the course materials by themselves from internet, television etc. They discussed the topics of news-based materials with his/her pair. They started to discuss the news by using W-H questions, namely; who, what, where, why, when, and how. The lecturer has role as facilitator and consultant of the students in learning. It involved several learning activities, such as; preparing the news-based materials taken from $\mathrm{BBC}$ news, international yahoo news, magazine, etc, making group in pair, reading carefully the news-based materials, discussing the essential things from the news, conclude the news orally, and presenting in front of the class. This study was experimental research design and applied quantitative method. The students of English Education Study Program of Muhammadiyah University of Parepare taken as the subject of this research. They were taught speaking course through the implementation of paired conversation activity by utilizing news-based materials. Through this treatment, it was found out that paired conversation activity by utilizing news-based materials has good effects in improving the students' speaking skill. Besides, the students also gave positive responses toward the application of paired conversation activity by utilizing news-based material for teaching-learning EFL speaking. This technique allows the students got the good opportunity to speak at length and helps them to develop their oral language proficiency.
\end{abstract}

Keywords: Paired Conversation Activity, News-Based Materials, Speaking Skill 


\section{Introduction}

As language teachers and lecturers in the $21^{\text {st }}$ century live in critical times. Our world faces serious global issues of terrorism, ethnic conflict, social inequality, and environmental destruction. Global approach is a new approach to language teaching that aims to enable students to effectively acquire a foreign langage while empowering them with the knowledge, skills, and commitment required by world citizens to solve global problems. Global education has been defined as education which multicultural, interdependent world (Fisher and Hicks, 1985).

The goals of a "global" approach to education are generally divided into knowledge, skills, attitudes, and action:

a. Knowledge about world problems is the first goal. If we want students to work for a better world, they must know the nature of world problems, their causes, and viable solutions.

b. Acquiring skills communication, critical and creative thinking, cooperative problem solving, nonviolent conflict resolution, informed decision making, and the ability to see issues from multiple perspectives necessary to solve world problems is the second goal.

c. Acquiring global attitudes global awareness, curiosty, an appreciation of other cultures, respect for diversity, a commitment to justice, and empathy with others in the third goal. d. The final goal of global education is action democratic participation in the local and global community to solve world problems.

Teaching English in university level is intended to develop the students' communicative competence which is emphasized the form of language skills covering listening, speaking, reading and writing. Listening as well as speaking is an essential component in communication. We always want to know what other people say and what we hear. If we can communicate in English, it means that other people can understand what we say.

Speaking is the most important skill, because it is one of the abilities to carry out conversation. Speaking is an interactive process of constructing meaning that involves producing, receiving, and processing information. The students should have the ability to speak English in order that they can communicate with others.

English speaking is one way of finding information through oral communication in the world. One who knows English well can easily associate with the other peopleall over the world and by this capability; he/she can apply for a job easily, spread news, works out his social relation or transact his business. There are many communicative activities to improve students' speaking ability. The most common kinds of productive model is conversation(Aswad 2017).

In response to catering of the needs of having good acquisition of English as foreign language, for Indonesian context, the hopes and expectation are put upon the teaching of language at schools and other courses. In the impelementation level for 
acquisition, classroom will most of the time become the stage for practicing and reflecting the real-life use of the language that may take place in the classroom. Using English for speaking is complicated rather than simple way, because the speakers should master several important elements such as pronunciation, grammar, vocabulary, fluency, and comprehension. In that case, the teacher should be creative in teaching-learning process to create good atmosphere, improve the students speaking competence, give attention to the element of speaking and make the English lesson more exiciting and fun.

In university level, teaching speaking needs appropriate technique in order that the students are active and creative in speaking class. One of good techniques that can be applied in classroom is "Paired Conversation Activity". It is a good activity for learning foreign language. It encouragescreative thinking, lets the students develop and active new language and behavioral skills in a relatively nonthreatening setting and can create motivation and involvement necessary for learning. Besides, this activity will be based on topics of news-based materials. In other words, the students will conduct paired conversation by utilizing news-based materias. They will talk and discuss several topics that covering news. This activity encourages the students actively participate in teaching learning process because this way provides a way of creating a rich communicative environment where the students actively become a part in a group.

This study will be focused on news-based materials, concerning with the use of website updated weekly with current news stories as a central feature of the course. This would function as a medium for presenting lesson content and for students to interact with the weekly topic and each other by adding their comments and opinions. The researcher will plan to examine the results of student interaction with the course content and to discover students' opinions and reactions in utilizing news-based materials. This study will therefore look at some of the decisions that went into the course design process and explain the effect of paired conversation activity.

This activity is potential attempt to cultivate a more communicative classroom. Harumi (2011) contended that communication activities should be designed to develop learner confidence and facilitate learners' autonomy in a classroom environment that encourages mutual participation. Watanabe (2013) similarly argued that learners need opportunities for student-centered and individually focused activities on realistic issues. With these explanations in mind, the researcher designed a research to study "The Effect of Paired Conversation Activity by Utilizing News-Based Materials in Improving the Students' Speaking Skill”.

In line with the background, the problem can be formulated as the following:

"How is the effect of paired conversation activity by utilizing news-based materials in improving the students' speaking skill?”

Harmer (third edition) stated that to decide how to put individual students into pairs and groups, and with which of their classmates. We can base such decision on any one of the following principles; 
a. Friendship, a key consideration when putting students in pairs or groups is to make sure that we put friends with friends, rather than risking the possibility of people working with others whom they find difficult or unpleasant. Through observation, therefore, we can see which students get on with which of their classmates and make use of this observation later. Perhaps, then, we should leave it to the students, and ask them to get into pairs or groups with whom they want to. In such as situation we can be sure that members of our class will gravitate towards people they like, admire, or want to be liked by.

b. Streaming, much discussion centres round whether students should be streamed according to their ability. One suggestion is that pairs and groups should have mixture of weaker and stronger students. In such groups, the more able students can help their less fluent or knowledgeable colleagues, the process of helping will help such strong students to understand more about the language themselves. The weaker students will benefit from the help they get.

c. Chance, we can also group students by 'chance' - that is for no special reasons of friendship, ability, or level of participation. This is by far the easiest way of doing things since it demands little pre-planning, and, by its very arbitrarianess, stresses the cooperative nature of working together. One way of grouping people is to have students who are sitting next to near to each other work in pairs or groups. A problem can occur, though, with students who always sit in the same place since it means that they will always be in the same pairs or groups which could give rise to boredom over a prolonged period.

d. Changing groups, just because we put students in groups at the beginning of an activity does not mean that they have to stay in these groups until the end. The group may change while an activity continues.

Harmer (third edition) stated that our role in pairworks does not end when we decide which students should work together, of course. We have other matters to address too, not only before the activity starts but also during and after it;

a. Before, when we want students to work together in pairs or groups we will follow the 'engage-instruct-initate' sequence. This is because students need to feel enthusiastic about what they are going to do. They need to understand what they are going to do, and they need to be given an idea of when they will have finished the task they are going to get involved in. Sometimes our instructions will involve a demonstration. On other occasions, where an activity is familiar, we may simply give them an instruction to practice language they are studying in pairs, or to use their dictionaries to find specific bits of information. To success of a pairwork task is often helped by giving students time when the activity should finish - and then 
sticking to it. This helps to give them a clear framework to work within.

b. During, while students are working in pairs, we have a number of options. We could, for instance, stand at the front or the side of the class (or at the back or anywhere else in the room) and keep an eye on what is happening, noting who appears to be stuck or disengaged, or about to finish. In this position, we can 'turn in' to a particular pair or group from some distance away. We can then decide whether to go over and help that pair or group. When students are working in pairs or groups we have an ideal opportunity to work with individual students whom we feel would benefit from our attention. We also have a great chance to act as observer, picking up information about students' progress.

c. After, when pairs stop working together we need to organize feedback. We want to let them discuss what occurred during the groupwork session and, where necessary, add our own assessments and make corrections. Where pairwork has formed part of a practice session, our feedback may take the form of having a few pairs or groups quickly demonstrate the language they have been using. Where students have produced a piece of work, we can give them a chance to demonstrate this to other students in the class. Finally, it is vital to remember that constructive feedback on the content of student work can greatly enhance students' future motivation. The feedback we give on language mistakes.

In pairwork, the students can practice language together, study a text, research language or take part in information-gap activites. They can write dialogues, predict the content of reading texts, or compare on what they have listened to or seen. Harmer (third edition) stated the advantages of pairwork, they are;

a. It dramatically increases the amount of speaking time any one student gets in the class.

b. It allows students to work and interact independently without the necessary guidance of the teacher, thus promoting learner independence.

c. It allows teachers time to work with one or to pairs while the other students continue working.

d. It recognizes the old maxim that two heads are better than one and in promoting cooperation helps the classroom to become a more relaxed and friendly place. If we get students to make decisions in pairs (such as deciding on the correct answers to questions about a reading text), we allow them to share responsibility rather than having to bear the whole weight themselves.

e. It is relatively quick and easy to organize.

The core of each lesson was therefore the article news, condensed and adapted from news websites such as BBC news or CNN by each teacher in turn every meeting. The news stories will be chosen for both their inherent interest and currency; each story 
will be about an event that had happened in the previous week and possibly be familiar to students who followed events in the news. The structure of this material will be represented in the form of concentrating on language and report. It means that it will focus on reading current news topic, highlighting vocabulary and students' opinion. In other words, the students will express their reaction to the news content and topic. To maximize the students' interaction in class and facilitate language learning, as well as provide a way of dealing with the difficulties imposed by the use of this material (Erbaggio, Gopalakrishnan, Hoobs, and Liu, 2010), a communicative approach using a task cycle was adopted, based on Marchand's (2011) previous syllabus. While the first stages of the task cycle are carried out in the classroom, it was the aim of the authors to facilitate an environment where students could extend their interaction with the materials and create a context where further learning could take place.

\section{Method}

This research was conducted in Parepare town, especially at second semester students of English Education Study Program of FKIP of Muhammadiyah University of Parepare (UMPAR). The population of the research were students of Faculty of Teachers Training and Education (FKIP) especially the second semester students of English Education Study Program of Muhammadiyah University of Parepare. The researcher applied simple random sampling. This sample of this research was 25 students. In this research, the researcher applied quantitative research method. It was pre-experimental design. The data were analyzed by using quantitative approach. The researcher gave the students speaking test to find out the students' speaking skill toward the paired conversation activity by utilizing newsbased materials.

The students learned speaking course through paired conversation activity by utilizing news-based materials. This treatment was conducted for five times meetings. The researcher divided the class into several pairs. It means that, every group consists of two students. The students speak and discuss in pairs. In every meeting, the researcher will distribute them several topics of news. The news were current isssues. They were taken from different sources, such as; $\mathrm{BBC}, \mathrm{CNN}$, international yahoo news, magazines and newspaper. In brief, this learning process utilized news-based materials as good and potential materials. The process of this treatment was guided and facilitated by researcher. In this treatment process guided the students to comprehend the content of news and express orally their comprehension, comments, and opinion to the news. The following are the procedures of this treatment, namely;

a. The researcher distributed a news that written in a worksheet to each pair.

b. The researcher instructed the students to read carefully the news article.

c. The researcher instructed them to comprehend the content of news.

d. The researcher asked them to discuss the essential points in the news article with their pairs.

e. The students were guided to concentrate on language in the news article. In this case, 
they have to read current news topic and highlight vocabulary.

f. The students also will be guided to report their opinions and comments. In this case. They expressed their reaction to the news article.

g. The researcher invited every pair to report orally their responses toward the content of news article.

\section{Findings and Discussion}

\section{a. The Result of Speaking Test}

To obtain the data, the test was given to the students. It purposes to know the result of the Effect on the Paired Conversation Activity by Utilizing News-based Materials in Improving the Students' Speaking Skill. The researcher involved a class that consists of 25 students. The researcher used pre-test and post-test. The pretest has been done before treatment process (teaching speaking skill by applying Paired Conversation Activity by Utilizing News-based Materials). This test is given to know the basic competence for all students and to know their earlier knowledge before they get treatment. The students score before getting treatment by using Paired Conversation Activity by Utilizing News-based Materials as teaching speaking skills process are very low compared and, just only few students can speak be better. The results of the students' speaking skill test were analyzed, and the analysis is shown in the following table:
Table 1. The Frequency and Percentage of the Students' score in Pretest

\begin{tabular}{ccccc}
\hline No. & Range of Score & Classification & $\mathbf{F}$ & $\mathbf{( \% )}$ \\
\hline 1. & $85-100$ & Very good & 0 & $0 \%$ \\
2. & $70-84$ & Good & 2 & $8 \%$ \\
3. & $55-69$ & Fair & 12 & $48 \%$ \\
4. & $50-54$ & Poor & 8 & $32 \%$ \\
5. & $0-49$ & Very poor & 3 & $12 \%$ \\
\hline & Total & & 25 & $100 \%$ \\
\hline
\end{tabular}

Table 2. The Frequency and Percentage of the Students' score in Posttest

\begin{tabular}{ccccc}
\hline No. & Range of Score & Classification & $\mathbf{F}$ & $\mathbf{( \% )}$ \\
\hline 1. & $85-100$ & Very good & 2 & $8 \%$ \\
2. & $70-84$ & Good & 8 & $32 \%$ \\
3. & $55-69$ & Fair & 11 & $44 \%$ \\
4. & $50-54$ & Poor & 4 & $16 \%$ \\
5. & $0-49$ & Very poor & 0 & $0 \%$ \\
\hline & Total & & 25 & $100 \%$ \\
\hline
\end{tabular}

Based on Table 1 and 2 indicated that there is a significant improvement from pretest to posttest. It can be noted that the students' speaking skill increased after being taught by using Paired Conversation Activity by Utilizing News-based Materials. Although, some students still got low scores, but it is getting development of gained score.

Table 3. The Mean Score of Students' Pretest and Posttest

\begin{tabular}{cc}
\hline & Mean Score \\
\hline Pretest & 56.80 (Pretest) \\
Posttest & 67.88 (Posttest) \\
\hline
\end{tabular}


After calculating the result score of the students' tests, the mean score of both tests obtained by the students in pretest was 56.80 , and in posttest was 67.88. it indicated the mean score of posttest was the greater than the mean score of pretest. To know the significant difference between the results of students' mean score on both tests, the researcher used t-test (test of significant). It is to see whether Paired conversation activity by utilizing news-based materials has good effects in improving the students' speaking skill. The result is showed on Table 4. below.

Table 4. The t-test value of the Students

\begin{tabular}{ccc}
\hline t-test & Df & t-table \\
\hline 3.820 & 25 & 2.064 \\
\hline
\end{tabular}

After calculating the students' score before and after getting treatment, the researcher found that the t-test value (3.820) was higher than $\mathrm{t}$-table value (2.064). Based on this analysis, it was concluded that the null hypothesis $\left(\mathrm{H}_{\mathrm{o}}\right)$ was rejected and alternative hypothesis $\left(\mathrm{H}_{\mathrm{a}}\right)$ was accepted. It means that Paired conversation activity by utilizing news-based materials has good effects in improving the students' speaking skill.

\section{b. The Students' Speaking Activites in Classroom}

The students were expected to know how tell their activites in speaking English and to make paired conversation about some materials taken several news. The researcher applied paired conversation activity by utilizing newsbased materials. In this activites, the researcher distributed some topics of reading texts taken from some sources of news to every pair. Then, they read the given topics and discuss it with their pairs. The started their conversation by using Wh-questions relating the news and finding difficult words.

The researcher instructed every pair to come in front of the class to practice their discussion result. This activity was good enough because the students were active in speaking during the English learning process in the class. This technique also gets the students' attention. Most of them could minimize their fears and shy to speak so they could speak without any worries although sometimes they made mistakes. Therefore, the level of student's concentration increased so the students could understand the course well.

\section{c. The Students' Responses Toward Paired Conversation Activity by Utilizing News-Based Materials}

The students also gave positive responses toward the application of paired conversation activity by utilizing news-based material for teaching-learning EFL speaking. This was shown by the results from the questionnaire where most students ( $80 \%$ of the students) were excited to practice this technique while learning speaking. They said that they enjoyed learning speaking through paired conversation activity by utilizing news-based materials since they could improve their vocabulary as well as their 
pronunciation. By applying this technique, the students got the good opportunity to speak at length. Besides, $75 \%$ of the students said that this technique helped them to develop their oral language proficiency as well as their reading comprehension ability. In fact, this technique allowed them to gain knowledge about the essential things of reading texts, such as; the main idea, the topic, unfamiliar words.

Based on the result of the data analysis, the researcher presents the discussion of the data analysis. Before giving treatment, most of the students' speaking skill was categorized fair, poor and very poor. It was proved by the percentage of total score of pretest. The mean score of pretest obtained by the students was 56.80. After giving treatment, the students' achievement at speaking skill showed that the students had good achievement. It was indicated by the mean score from the posttest, it was 67.88 . It revealed that the mean score gained by both tests was quite different (11.08).

In the t-test statistical analysis, the result of the t-test value (3.820) was greater than the t-table value (2.064). It meant that the $\mathrm{H}_{\mathrm{a}}$ was accepted and $\mathrm{H}_{0}$ was rejected. This figures out the students had better ability after they got special treatment in teaching process. It means that the achievement of the students after they taught by using Paired conversation activity by utilizing news-based materials has good effects in improving the students' speaking skill.

The students also gave positive responses to the paired conversation activity by utilizing news-based materials. The materials were taught to them were current issues. It encouraged the students to learn the passages because they were materials with which they were familiar. Thus, it could be said that the responses of the students to the application of paired conversation activity by utilizing news-based materials for teaching speaking skill was positive. As a result, the students not only improved in social relationships with their friends. So, teachinglearning by applying paired conversation activity by utilizing news-based materials is an effective technique to use which has been proved in other previous studies done by other researchers and which concur with the findings from this study.

Moreover, the result of this research supported expalanation stated by Harmer (Third Edition) that this activity has some advantages. The application of this activity can build up the friendship because in learning process the students make pairs that we put friends with friends. Besides, in pairs and groups have been placed thr mixture of weaker and stronger students. As a result, the students are able to help their less fluent or knowledgeable students. That's way, the weaker students will benefit from the help they get. Other adavantages of this activity are it increases the amount of speaking time in class because the get good chance to express their ideas with their pair. This activity also allows the students to interact and communicate with their pair based on the lecturer's guidance.

The result of this research also showed that by utilizing the news-based materials in speaking 
teaching and learning process can maximize the students' interaction and communication in class. Besides, this media also can facilitate the language learning and extend their concentration on learning topic such as current news topic, and highlighting vocabulary. It supported explanation from Erbaggio, Gopalakrishnan, Hoobs, and Liu (2010) that news-based materials are good and potential materials can be facilitator media and improve communicative skill.

\section{Conclusion}

Based on the findings, the researcher concludes that Paired conversation activity by utilizing newsbased materials has good effects in improving the students' speaking skill. It is proved by the mean score obtained from the students' pretest (before getting treatment by using Paired conversation activity by utilizing news-based materials) only 56.80. After the students were given treatments by using Paired conversation activity by utilizing news-based materials, the mean score was 67.88. It revealed that the mean score gained by both tests was quite different (11.08). In applying t-test of the students, it is found that the t-test value (3.820) is greater than t-table value (2.064). In other words, paired conversation activity by utilizing news-based materials is effective in involving the students in speaking in real life situations and useful technique that helped them improve their speaking ability. Besides, the class become more lively, interesting and the teacher are more creative in making or searching for news that the students will love, and always be interested and enthusiastic when learning English. In relation to this conclusion, the researcher suggests to te next researchers to conduct studies of modifying a lot of news-based materials then integrated in English language teaching. The modifications of these newsbased materials can be contributive materials in developing other language skills such as listening, writing and reading.

\section{References}

Aswad, Muhammad. 2017. "Is It Truly Improvisational Exercise Push Students' Speaking Ability." EDUVELOP (Journal of English Education and Development) 1 (1): 9-17.

BBC World Service. 2003. Learning English Better Speaking. A Guide to Improve Your Spoken English. British Broadcasting Corporation.

Boonkit. 2010. Enhancing the Development of Speaking Skills for Non-Native Speakers of English. Thailand: Elseiver. Accessed: Wednesday, February 20, 2015.

Brown. 2000. Teaching by Principles. United States of America: Longman. Accessed: Wednesday, February 20, 2015

Brown. 2004. Language Assessment Principle and Classroom Practice. San Francisco: Longman. Accessed: Wednesday, January [18, 2015.

DeSteffen, Christopher. 2015. The Effect of a TopicBased Paired Conversation Activity on the Confidence of Japanese EFL Students to Utilize English Orally. International Journal of English Language Teaching, Volume 2, No. 2, 2015. http://ijelt.sciedupers.com. Accessed on 3 Maret 2016.

Gay, L.R., Mills, Geoffrey E., Airasian, Peter. 2006. Educational Research: Competencies for Analysis and Applications ( $8^{\text {th }}$ Edition). Upper Saddle River, New Jersey Columbus, Ohio: Pearson.

Harmer, J. 2001. The Practice of English Language Teaching. Cambridge: Longman. Accessed: Wednesday, January 18, 2015.

Harmer, Jeremy. The Practice of English Language Teaching. Third Edition. United Kingdom: Cambridge Press.

\section{6}


Harumi, S. 2011. Classroom Silence: Voices from Japanese EFL Learners. ELT Journal, Page 260-269. http:// dx.doi.org/10.1093/elt/ccq046.

Jabu, Baso. 2008. English Language Testing. Makassar: Badan Penerbit UNM.

Jodai, Hojat. 2011. An Introduction to Psycholinguistics. Published Journal, The University of Guilan.

Panambunan, Emelia, Golda J. Tulung, and Mister Gidion Maru. 2016. Improving Students Speaking Ability Through Communicative Language Teaching of the Second Level Students at "MEC Megalia English Course. JELLT Volume 1, No. 1, November 2016. Accessed on 5 July 2017.

Safwandi. 2016. Teaching Speaking with The TeamsGames Tournaments Technique. English Education Journal (EEJ), Volume 7, Issue 2, Page 206-218. Universitas of Syiah Kuala, Banda Aceh. Accessed on $3^{\text {rd }}$ September 2017.

Tim Marchand and Rowlett, Benedict. 2013. Course Design in the Digital Age: Learning Through
Interaction with News-Based Materials. Journal of CAMTESOL, Language Education in Asia (LEiA), Volume 4, Issue 2.

Tim Marchand, English Language Program, J. F. Oberlin Unversity, Machida, Tokyo, Japan. Benedict Rowlett, Department of Commerce, Chuo University, Hachioji, Tokyo, Japan.

Torky. 2006. The Effectiveness of a Task-Based Instruction program in Developing the English Language Speaking Skills of Secondary Stage Students. Ain Shams University. Accessed: Wednesday, May 20, [2015.

Trinity. Language Activities for a Communicative Classroom. London: CBSE. Accessed: Tuesday, January 5, 2015.

Watanabe, M. 2013. Willingness to Communicate and Japanese High School Language Learners. The Japan Association for Language Teacher Journal. Page 1531 